\title{
River Erosion: Vulnerability \& Its Social Consequences on the Life of Women: A Study at Chondonbaisha \& Kutubpur in Sariakandi, Bogra
}

\author{
A. M. Rezwanul Hoque ${ }^{1} \&$ Md. Reazul Haque ${ }^{1}$ \\ ${ }^{1}$ Department of Development Studies, University of Dhaka, Bangladesh \\ Correspondence: Md. Reazul Haque, Department of Development Studies, University of Dhaka, Bangladesh. \\ E-mail: reaz.devstud@gmail.com
}

$\begin{array}{lr}\text { Received: May 8, } 2013 & \text { Accepted: May 31, } 2013 \quad \text { Online Published: July 19, } 2013 \\ \text { doi:10.5539/res.v5n4p99 } & \text { URL: http://dx.doi.org/10.5539/res.v5n4p99 }\end{array}$

\begin{abstract}
This paper explores women's social conditions and vulnerability after the River Erosion (RE) at Sarikandi \& Kutubpur in Bogra, Bangladesh. It discuss the vulnerability framework by Moser and capabilities approach by M. Nussbaum, then applies them to the study of deprivation of capabilities in the life these affected women. Here the research technique is both primary and secondary method and to collect data in standardized manner semi-structured questionnaire, In-depth Interview are used. RE is the most unpredictable type of disaster and due to it, every year a large number of people have displaced from their homestead. After RE these people, with their economic assets; also lose their social bonding. In rural area of Bangladesh, social bonding act as social capital but with displacement; all their bondage and capitals are gone. After migration in a new place, nothing is familiar to their previous life. Because of the unfamiliarity, they lose their practical reasoning as well as their ability to control over environment. Many initiatives are taken to help these destitute women but the most important initiatives; proper tributary management is not taken into concern yet. Without proper tributary management the threat and vulnerability will remain same to these women. So, proper concern about the issue is needed here. In this paper it has explored different arguments about the deprivation of capabilities and absence of agency in these women's life. And at the end, there are given some recommendation in order to improve the social conditions of these women.
\end{abstract}

Keywords: women, river erosion, vulnerability, capabilities

\section{Introduction}

The people of Bangladesh are highly vulnerable to the river erosion (RE). It is one of the most unpredictable and critical type of disasters that takes into the country because of quantity of rainfall, soil structure, river morphology, topography of river and adjacent areas, and floods (MWR) (Note 1). Geographically, Bangladesh situated in a region where various disaster take place most often. Bangladesh is situated between the Himalayas and the Bay of Bengal together with tropical monsoon climate. The catchment area of the major rivers is about 1.65 million square $\mathrm{km}$ of which only 7.5 percent lies within the border of Bangladesh that generates $1200 \mathrm{~km} 3$ of run-off annually, only 10 percent of which is generated within Bangladesh (CEGIS, 2000; Sarker et al., 2003). In addition to vast quantities of water, these rivers carry about 1.1 billion tons of sediment every year (Ibid) and are responsible for the prevalence of flooding and river erosion in Bangladesh (Elahi et al, 1991). Study findings by Center for Environment and Geographic Information Services (CEGIS, 2009) based upon analysis of 30-year time series of satellite images reveals that the Jamuna and Padma rivers have widened more than three kilometers and destroyed about 130000 hectare of floodplain land. So every year this country and its people have to cope up this hazardous situation (Note 2).

$\mathrm{RE}$ creates economic, environmental and social hazards. But most of the cases the priority goes to the economic issues rather than the environmental or social issues. It has no doubt that because of RE people of this country has to lose a large amount of their assets, but they also have to suffer from various social issues. Both men and women are the sufferer of this disaster but most of the cases women are excluded from various programs and plan that has been taken by government and Non-Government Organizations (NGO's). Actually our policies (River policy and Water policy) (Note 3) and other programs build up in such a manner that most of the cases women are neglected.

In Bangladesh, like everywhere of the world, the worst victims of the environmental degradation are women (Wasata \& Haque, 2011). Here, particularly, women suffer much more severely than their male counterpart for 
any kind of environmental degradation. For example, absence of secure living room can cause more security problems for a woman than a man. Therefore, environmental degradation can reason comparatively much harm to women comparative to men.

There are various works related on the issues RE, but unfortunately all of them are tend to find out the economic looses, and viewed through the lenses of male perspectives. Many times various activities are being taken to cope up with RE, where either woman is sided away or the initiatives are a holistic one. It is true that both men and women are affected by RE but women are the worst victim of RE due their role of homemaker, looking after the children, caring for the old, sick and pregnant women of their household. Thus, in this research both sociological consequences' and vulnerability of RE are analyzed throughout the lenses of female. Furthermore, this study can contribute in various studies especially in development studies, deserter management, women and gender studies etc as well as in the field of knowledge.

$\mathrm{RE}$ is one of the major natural calamities of Bangladesh that took place in almost every year. The main objective of the study is to find out the social effects of RE on the livelihood of the affected women of Chondonbaisha \& Kutubpur in Sariakandi, Bogra. The main question that this paper will deals is What social consequences women are facing face in Chondonbaisha \& Kutubpur in Sariakandi, Bogra due to RE? Other questions of this paper are as follows:

$\checkmark$ Does RE is an environmental-related problem, or a unique combination of both environment and development project in the study area?

$\checkmark \quad$ What are present social situation of those women who are migrated in other places due to RE?

$\checkmark \quad$ What are the government initiatives to support those vulnerable women?

$\checkmark \quad$ Is there are any biases in the State's response? If there any, then what are the factors that contributing to the biasness?

$\checkmark$ How media and civil societies, especially various development organizations addressing this problem?

$\checkmark$ Do cast, religion and other social issues have any roles to play in the vulnerability issue?

This paper is based on both primary and secondary data. Feminist research methodology has been used. Thirteen respondents (Women, Government Official, Local Leader, NGO activists, person from media and people from civil society) have been interviewed through semi- structured interview schedule. Focus group discussion was conducted. Issue of ethics was strictly maintained during interview process.

The research is divided into five sections. In The first section highlighted the problem statements. This section also has given the rationale, objectives and the research question. The methodology has been portrayed here with other necessary information of the research. The second section deals the works of the prior academicians on the issue RE. Based on the prior works, the operational definition and the probable theoretical framework have also been pictured here on the basis of which the overall research has been conducted. The third and fourth section covers data analysis. These sections have elucidated the sociological position and livelihood situation of the stakeholders in the research area. In the last section findings are summarized under Nussbaum's list of ten capabilities which is not fulfilled in relation to those affected women. Later in the section are also given some recommendation about the procedure of improvement of social life of these vulnerable women.

\section{Literature Review: Vulnerabilities and Restraint of Capabilities in the Social Life of Affected Women}

To make the research more understandable, it is essential to conceptualize the relevant key concepts. This chapter conceptualizes some key concepts, through which the analysis takes place. The major concepts related to this research are Vulnerability of women; women's sociological position in a RE affected area. And because of $\mathrm{RE}$ how their capabilities are being constrained is also a key concept here.

\subsection{Vulnerability: The Asset Vulnerability Framework and Women}

Vulnerability is the possibility of being affected by adverse situation. The word has emerged as a central concept for understanding what it is about the condition of people that enables a hazard to become a disaster (Tapsell, et. al, 2010). The asset vulnerability framework is based on the work of Caroline O. N. Moser; where vulnerability is being defined under some frameworks. According to her it should be the policy to identify what the poor have (asset), rather than what they do not have to cope up with vulnerability (Moser, 1988:23). She defines assets of poor in two groups, tangible assets, such as labor and human capital, and productive assets, such as housing, as well as intangible assets, such as household relations (ibid).

There is a close linkage among vulnerability, assets and poverty. From the result of the frameworks of Moser it 
has been found that the poor themselves are managers of complex asset portfolios. In her framework, the concept vulnerability is being linked and schematized under five categories and then she ends in a conclusion that asset management may reduce the household vulnerability (Moser, 1998:23). Although the concept of vulnerability is often used as a synonym for poverty, but it is not the same. Because poverty measures are generally fixed in time, but poverty is essentially a static concept (ibid). In contrast, vulnerability is more dynamic and better captures change processes as 'people move in and out of poverty' (Lipton \& Maxwell, 1992:10). It is true that poor people (Note 4) are usually among the most vulnerable group, but not all vulnerable people are poor, a distinction which facilitates differentiation among lower-income populations. Again vulnerability does not always mean the disaster of poor rather vulnerability stands for the possibility to fall in disaster. It has been found that hazard by itself is not a disaster unless there are vulnerable populations who do not have the capacity to absorb it and who are unable to cope with it (O'Neil, 2010). O'Neil tried to analyze Vulnerability this framework -

\section{Disaster=Hazard x Vulnerability (Note 5).}

In his framework he stated that both hazard and vulnerability present in peoples' life but they are not always so destructive. When disaster affects peoples' life the vulnerability and hazard are being multiplied with each other and turns into a big shock to them. And at this time the hidden vulnerability stand as a treat to the affected people.

Both in normal and disaster time, it is women who have suffered more. The burden to cope up with the adverse situation goes more on women than men. Women have become easy victims of displacement because of their role of homemaker, looking after the children, caring for the old, sick and pregnant women of their household (ibid). In a patriarchal society (Note 6) where women have to do various types of works, women are more vulnerable than men and the time of disaster like RE their vulnerability rises into twice or thrice times. In O'Neil's words:

It has been seen from the field survey that women are not a homogenous category and the degree of their vulnerability and sufferings in times of displacement depended on their socially significant personal attributes like age, religion, education and household attributes like asset owning (mainly land), presence of male members, number of times of being displaced, place of relocation, and so on. As for example, belonging to particular religious category can also determine the degree of women's vulnerability in times of displacement. ${ }^{4}$

Vulnerability and its effects on women's life may vary due to various reasons. But any definition requires the identification of two dimensions of vulnerability; its sensitivity (the magnitude of a system's response to an external event), and its resilience (the ease and rapidity of a system's recovery from stress) (Blaikie \& Brookfield, 1987; Bayliss-Smith, 1991). Thus an urban RE affected women bears less vulnerability than the RE affected women of rural as the option to response in any adverse situation is wider in urban area (Moser, 1998).

\subsection{Dissimilarity of Vulnerability \& Capability}

There are important distinction between vulnerability and capability. In arguing that Moser (1998) stated that enhancement of capabilities may have the possibility to reduce the vulnerability but never be the cure. In Moser's words

Development is a process through which people's physical/material; social/organizational and motivational/attitudinal vulnerabilities (or capacities) are reduced or increased (Moser, 1988:23).

The core focus of the capability approach is on what individuals are able to do (i.e., capable of) (Sen, 1985). Capability is thus a set of factors of functioning, one type of life or another (Sen in Alexander, 2002:3). A person's functioning and her capabilities are related but distinctive in nature. Functioning is, in a sense, more directly related to living conditions, since there are different aspects of living conditions (Sen in Alexander, 2002: 4). The combination of a person's functioning represents their actual achievements; their capability set represents their opportunity freedom - their freedom to choose between alternative functioning combinations (Sen, 1999).

Women of Sariakandi are the worst victim of vulnerability. Their basic needs are not ensured and developments of their capabilities are also constrained because in vulnerable situation the capabilities of individuals and households are deeply influenced by factors ranging from the prospects of earning a living, to the social and psychological effects of deprivation and exclusion. These include people's basic needs, employment at reasonable wages and health and education facilities (Streeten, et al., 1981).

The propensity of being vulnerable has an inverse relationship with assets ownership. The more assets people have, the less vulnerable they are, and the greater the erosion of people's assets, the greater their insecurity (Moser, 1998). People's asset can be classifying five sources of entitlements as productive capital, 
non-productive capital, human capital, income and claims (Maxwell \& Smith, 1992). For that reason those who own more assets, have the greater possibility to move out from vulnerability, or have the capabilities to cope up with RE.

There stands another problem to the affected women of RE, that is social fragmentation. With displacement into new places women discovered themselves into a new situation where there exists a little bondage between the people. Now most of them are in needy situation but once they were in moral economy, where the right to make claims on others, and the obligation to transfer a good or service is embedded in the social and moral fabric of communities (Scott, 1976). After RE here happened a fragmentation, which hampers these people's social life. This fragmentation problem appears a great hindrance to their normal life. After being affected by RE these women are fell into social exclusion where there lacks mutual trust, belief on others. This situation creates the social vulnerability in that area, where social vulnerability is often hidden, and complex and nested in various human aspects (Fekete, 2008). But people of the affected area have the little time to think about their social lack as their basic needs are not ensured. Social exclusion of these women hampers their social relation as well as their social capital also. The term 'social capital' stands not only for the relation of people within the wider society but also stands for the nature of the relationships and the physical and societal environment they inhabit (Tapsell, et al., 2010).

It is undeniable that asset ownership reduces the vulnerability but sometimes the capacity to manage them also able to reduce vulnerability. There is a growing recognition that the poor are strategic managers of complex asset portfolios (Moser, 1998) which highlights the limitations of using unidimensional indicators of coping strategies to measures the 'complexities which need to be understood before they can be simplified for policy-making and implementation' (Davies, 1993: 68). As the vulnerability of men and women are not same and women are not homogenous group (O’Neil, 2010), economic and social impact of RE is not same in everywhere; unidimensional indicators of coping strategies are not applicable for all situation (Davies, 1993).

\subsection{Vulnerability and Capabilities: How One Constraint the Another?}

Development (Note 7) (Note 8) requires the removal of major sources of unfreedom: systemic social deprivation, neglect in providing basic public facilities etc. Sometimes the lack of substantive freedoms robs people of the freedom to satisfy hunger, to achieve sufficient nutrition or the opportunity of educational facilities (Sen, 2005). Due to RE suddenly the lifestyle of those women are being changed and now in most of the cases their basic need is not ensured. They cannot get necessary health services, have less access to education, less job is available for them. Every time their life has limited into a few options and thus they also have less negotiation power. Deprivation exists in everywhere in their life and they may never able to reach the ultimate stage of capabilities named freedom of choice, which is stated by Sen in his theory. Here I also used the capabilities approach of Nussbaum. The basic capabilities approach has been pioneered by the Amartya Sen and more recently also been significantly developed by the Liberal feminist and theorist Nussbaum (Wahab \& Haque, 2011) where the basic focus goes to social justice. She expands the list of capabilities to bodily life, bodily health, bodily integrity, imagination and thought, emotions, practical reason, affiliations, play, other species and control over environment (Nussbaum, 2005:172-173). Sen (2000) stated that:

People have the freedoms (capabilities) to lead the kind of lives they want to lead, to do what they want to do and be the person they want to be. Once they effectively have these freedoms, they can choose to act on those freedoms in line with their own ideas of the kind of life they want to live (ibid).

The major constituents of the capability approach are functionings and capabilities. A person's functionings and his capability are closely related but distinct. According to Sen

A functioning is an achievement, whereas a capability is the ability to achieve. Functionings are, in a sense, more directly related to living conditions. Capabilities, in contrast, are notions of freedom in the positive sense: what real opportunities you have regarding the life you may lead (Sen, 2000).

Thus functionings are the "beings and doings" of a person, whereas a person's capability is "the various combinations of functionings that a person can achieve" (Sen, 1999).

Sen's version of the capability approach is broader and more general framework in comparison to Nussbaum's (Wahab \& Haque, 2011). Nussbaum formulates a well-defined but general list of 'central human capabilities. Based on the list of capabilities of her in this research paper I have focused on how RE constraint their capabilities? How RE stands as an obstacle for their well-being?

Does RE constraints the life and bodily health of the women of that region? Life is the ability to live to the end of a human life of normal length; not dying prematurely and Bodily Health is the ability to have good health, 
including reproductive health, the ability to have adequate shelter .where Bodily integrity stands for being able to move freely from place to place; being able to be secure against violent assault, including sexual assault (Nussbaum, 2001). How they lived before being by RE and now what are their living conditions, do they have facing any situation that affects their reproductive health and security against violent assault is focused here. Nussbaum defines Senses, imagination, thought as:

Senses, imagination, thought. Being able to use the senses; being able to imagine, to think, and to reason--and to do these things in ... a way informed and cultivated by an adequate education ...; ; being able to use imagination and thought in connection with experiencing, and producing expressive works and events of one's own choice ... ; being able to use one's mind in ways protected by guarantees of freedom of expression with respect to both political and artistic speech and freedom of religious exercise; being able to have pleasurable experiences and to avoid nonbeneficial pain (Nussbaum, 2001).

In the needy situation caused by RE do they have scope to think and imagine about their life, do they have any choice about their life or they only have to do what is available to them. Is there any scope for their emotions in their life? How love and care comes to them in the vulnerable situation is concerned here.

The practical reasoning the ability or engagements to plan about his/her own life as well as his future (Nussbaum, 2001). She stated that:

Being able to form a conception of the good and to engage in critical reflection about the planning of one's own life (This entails protection for the liberty of conscience and religious observance (ibid).

When they displaced into a new environment from their day to day life how their life is changed, how they cope up with various situation, what is the perception about their life is tried to find out here. In a life where everything is washed out by river, what they are future plan of their life is also focus here.

Affiliation is somewhat the ability to live for and in relation to others, to recognize and show concern for other human beings, to engage in various forms of social interaction; being able to imagine the situation of another and to have compassion for that situation (Nussbaum, 2001). Once they used to live in a moral society where the affiliation among the neighbor was the part of their life. Does the situation changed or remain same? Finding out how affiliation comes to them in a vulnerable situation is another issue here.

Other species is opportunity to live with concern for and in relation to animals, plants, and the world of nature, where play stands for the ability to laugh, to play, to enjoy recreational activities (Nussbaum, 2001). What recreational activities they have after RE? Is that hampered because of RE? Now what relation they have with nature is focused here.

Control over environment is defined as the perceived control an individual has over various characteristics of his/her environment. Nussbaum classifies control over one's environment into two different dimensions- political and material control over environment. In her words

Being able to participate effectively in political choices that govern one's life; having the right of political participation, protections of free speech and association. Being able to hold property (both land and movable goods), not just formally but in terms of real opportunity; having the freedom from unwarranted search and seizure (Nussbaum, 2001).

After being affected by RE how their political situation is changed than before is tried to focus here. Before RE what was their political influence and now what influence they have, what resources they have now, how RE changed their livelihoods' opportunity is another concern here. Based on above discussion there formulate a linkage between vulnerability, women and Social consequences in the analytical framework.

The schematic presentation of the research is as follows:

The relation between rivers and people of this country is inseparable. From ancient days, Bangladesh is dependent on agriculture where settlement was established around the bank of various rivers. Using the fertile land near to rivers and water of rivers, people used to cultivate form decade to decade.

The majority people of this country, who live along the river bank, are farmers. In Bangladesh, farmers grow many crops in the fertile lands beside rivers which are very important sources of their household income, but sometimes their livelihood (Note 9) patterns have been lost or changed because of bank erosion (similar findins have been found in a study by Naoki, M. Kengo, S \& Pech, S (2008) (Note 10).

Due to loss of residential house, cultivatable land, and other assets into rivers, RE becomes major concerned issues for local people who have lived along near the rivers. Local people do not have enough abilities to cope up and protecting their assets from RE. Thus sometimes river and its water appear as a serious threat to them. 


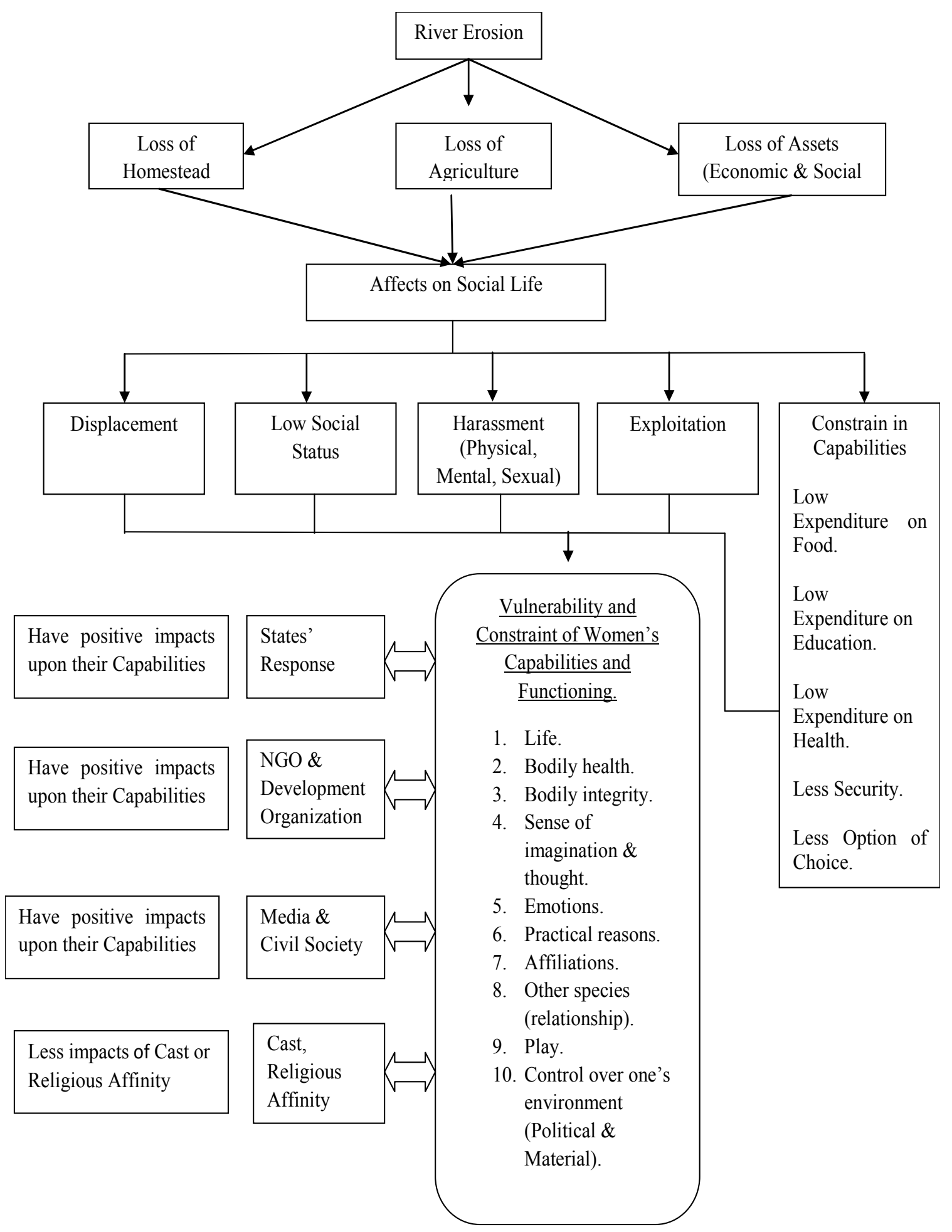

Figure 1. Impacts of RE upon capabilities in the life of affected women

\section{From a Beautiful Past to Nightmare}

In this section the primary data used to discuss socio-economic background, living and working conditions of affected women which is being collected from research areas namely Chondonbaisha \& Kutubpur in Sariakandi of Bogra. This chapter deals with the affected women's past and present socio-economic situation, their problems of lives, and their feelings about past and their hopes about the future. 


\subsection{Socio-Economic Background of the Respondents}

"Where rice is scare it is luxury to think about Biryani. (Note 11)"

In rural areas of Bangladesh most of the time the social status of one's is being determined by the amount of assets a person hold. The above quote was said by a respondent named Monira (Note 12). To her, where there is not ensured the basic needs it is a luxury to her to define her social life. One's social status in many cases is dependent on economic efficiency of that person.

The chart below shows the previous occupation of the respondents of the study:

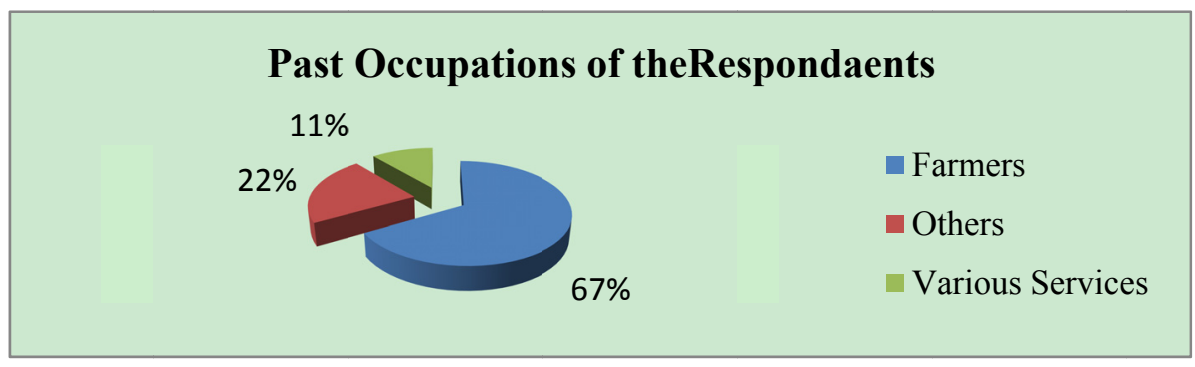

Figure 2. Past occupations of the respondents

The chart depicts that most of the women and their family members' past occupation was agriculture. Those who live near the river, most of them were directly or indirectly engaged in agriculture. By using the fertile land and water form river people used to grow crops there. But due erosion of river their livelihood pattern have been changed. This finding supports the statement of Naoki's Bank erosion the Mekong River Basin (2008). The author argued that the majority of people, who live near the river bank, are farmers; they grow many crops in the fertile lands beside the rivers. This cultivation is very important sources of their household income, but sometimes their livelihood (Note 13) patterns have been lost or changed because of bank erosion.

After RE women with other occupation also have to suffer. They also have to lose their previous occupation and assets with losing their husbands assets. But comparison with previous two groups, the farmers and other professionals, women who were engaged in service specially government service are in better position. Like previous two groups they are also affected by the RE, also they had to lose assets and homestead but unlike others they are not unemployed. They are able to continue their previous job and at least able to earn their livelihood.

\subsection{Their Past and Present Socio-Economic Situation}

\subsubsection{The Problem in Social Status of Women When Agriculture Sector is Being Exaggerated by RE}

Firstly, most of the farmers lose their cultivatable lands due to RE and now leading an unemployed life and that hampers their social situation as well as their economic situation. Suruja Begum was one of the rich farmer's wife, of her locality and was a respected woman in that area, told about her present social situation. According to her:

The social respect may be remain same for me but there added sympathy with it (Note 14).

As stated before, in this country, social status is highly dependent on economic position. So after being destitute by river one's social situation is not remaining same. The case study of Suruja Begum illustrates the situation more perfectly: 
Before RE my main job was to take care of various tasks of my family. I used to monitor the processing of the harvest which was come from my field. In combined I and my husband had 19 bighs (Note 15) of lands, which was enough for us to lead a satisfactory life. River erosion affected my life five times but last time, river washed away my all assets as well as my homestead. Within a one and half hour with my horror I saw that I am no more a rich farmer now rather than a refugee who is poorer than a bagger.

At present, I am in shelter of one of my neighbor's house who worked in my land before RE and used to call me master. Once that neighbor worked under me, I had some authority upon that person now I am a refugee at that person's home; both I and my husband are unemployed and we have to depend on that neighbor for food and other necessities. At this situation what social status and respect is remaining for me? My loss is more severe than others because those who are used to work in others land will be able to mange work because they will not hesitate to work under a new master. Because of my previous social status and habitual practice it is quite impossible for me to ask help from others or to work under a new master. Moreover those people who are well known about me and my husband's past will not eager to give us work as to them this will ruined a "respected people's respect."

When I walk in my territory all people are giving respect to me because they know that once this I owned a vast property; many people in this area were worked in my land and also got help from me. The situation has changed now. Now I am no more different from them. I get sympathy from various people which makes me recall about my golden days of past. Now I can realize that - the day is not so far when for me and my family, there exist only sympathy not respect.

Furthermore, those famers who used to work in others lands are now also in trouble as no works are available for them. Most of them are migrating in various nearby towns to fetch job which also hampers their social life. In village life, the social bonds among the neighbors' play a vital role. People are used to live in a friendly environment where everyone is known to each other; but when they moved to towns or other nearby cities obviously their life is being changed. And in most of the cases they found themselves in a place where no one is there to be called as their friends. The river flows in east side of the research area and RE takes places from east to west. One migrated respondent expressed her felling that:

We have to move toward west as river began to split away lands from east, the more we moved to west the less we found our known face and it is really tough to live in a place where you do not find any one whom you able to identify as your friend (Note 16).

Before RE they have their own village as well some neighbors with whom they were able to lead a happy life. After losing all by erosion they moved towards west as river split away land from east. They have to migrate into a new place where the environment is not as friendly as it was before. But as they have no choice they have to migrate themselves ignoring the past social relation's memory.

\subsubsection{The Problem in Social Status of Women When Other Professions are Being Exaggerated by RE}

Not only agricultural sector are affected by RE, but also other professions' are also victim of this disaster. Jahara is one of them who thinks because of RE her life has ruined. Bangladesh is a country where a woman's life and her status and happiness are closely related with her husband's life. She and her husband used to work as blacksmith in that area but RE takes their all assets and they became needy. In her words:

There is no homestead to live. All happiness and respect drowned with RE. My husband died, because he could not accept the reality. Now my daughter has to work as maid in town (Note 17).

Now Jahara is a widow, and to her it is the most painful thing that now she has to live her life alone as her husband passed way. Her daughter has to move to town as now she is not capable to provide her daughter's basic needs. She thinks that her social status was not same as it was before when her husband was alive because in a patriarchal society like Bangladesh most of the people think that widow women are in need of sympathy rather than respects. Again social discrimination against these widows is also high. They are deprived of their economic rights. They have no right to the family property and remain mostly in social isolation in the male dominated society and have no choice but to depend on their male relatives (Note 18). She expressed with frustration:

We were able to live a happy life. My daughter went to school. I used to engage in household chores and farming. 
Now those days are dream to me but except mourning I have nothing to do (Note 19.)

Moyna is a grocery shop owner. She and her family lives on the income of the shop. But now her business is seriously hampered as there is no business because there is no money in people's hand. In her words:

There is no business as people do not have money. If the situation continues I have stop the business and has to sell the shop (Note 20).

She lives on the income of her shop. But now the income is dramatically reduced. Every day she has to count losses. Before she was able to sell more than 3000 taka per day but after RE her sells decreased to one third of her previous per day selling and stands at 800-1000 taka per day. If the situation continues, she will have no alternative rather than closing her grocery shop which will make her economically vulnerable.

\subsubsection{Other Social Problems of Women Due to RE}

The issue of early marriage is quite common in our country. Because of female education and proper intervention of authority the rate falls in last few years. But after RE, the rates of early marriages of girls rise dramatically. There may be various reasons behind it. But it is found that erosion affected families are mainly wishing to give their daughters an early marriage. One of the respondents named Rupali, now searching an eligible groom for her 14 years daughter Shamima. To Rupali, now she and her daughter are living on the dam under a tent which is given by an NGO. Before RE her daughter used to go school but now she stopped to go there as the school drowned into water. At present, her family is not in a situation to send her in a private school. Rupali stated that all day her daughter has to stay in the tent. In addition, it is really risky for an adolescence girl to stay alone in tent as there may happen any occurrence. She remains always in tension when she is outside of the home for work. To Rupali when they lived in their own house everybody is known to them and in any problem everyone used to stand beside them. But the situation is not same now. There is lack of security in current place. Now it is mandatory for Rupali to arrange a marriage for her daughter is considered as early marriage. Because without early marriage it may create some problems in future, which will affect Shamima's marriage as everybody will say that:

That girl lives on the dam for many days, she may not be pure (Note 23) (Note 24).

Bangladesh is a country where sexual purity is treated as the most important virtue for a bride. No physical test is required to prove a girl's virginity, but reputation of sexual purity is crucial factor, rather than lost of virginity (Blanchet in Joseph, 2003) (Note 25). So if there stands any rumor about a girl that the girl is not pure she will has to face problem in the time of her marriage.

Rupali knows that it is not good for her and her daughter to arrange an early marriage. Government forbids early marriages (Before 18 years) but intriguing other factors, she justifies her daughter's early marriages. She opines that:

I know early marriage is not good but look at my situation, house and security. Do I have any alternatives (Note 26)?

Another problem stands there, that is the free raider problem. Everyone who lives on the dam is displaced from their farmstead. At present they are jobless. Kyallani is one of displaced women, said with grief that:

Here we have no scope to improve our situation (Note 27).

Previously, she used to grow vegetables in front of her house. After RE, few days ago she grew vegetables on the slope of dam. But everyone came and took her vegetables as it seems the vegetables belong to them. Her son tried to dissuade them from doing this but they did not take his word in their ear. Instead, one of them used slang and said:

Is this your father's field? It belongs to government. I will do what I want to do (Note 28).

After that incident, currently she is not eager to grow any vegetables there and thus her income generating has been stopped. According to her, now it is impossible for one improve his/her life with his/her own effort. If anyone try to do that there creates misunderstanding among the residence who are presently living on the dam.

Furthermore, now women have to find new work for themselves, which makes problem in many cases. Exploitation in wages and sexual harassment is not uncommon. As everyone is looking for work it is easy for the employer to exploit them. Here is another case study a widowed woman, which will illustrate the situation more perfectly. 
After the erosion, I (Note 29) went to one of my relative's house with my two daughters. The relative gave us shelters with a condition that I and my daughters have to work household chores. But after few days the relative's son began to disturb my elder daughter, who is sixteen years old. He always offered her daughter 'Kharap kaj' (Note 30). I am well known about the matter and I also know that my daughter has no guilt. But now I am not able to protest it as this is the only shelter for my family and by any means I do not want to lose it. Indirectly I tried to tell the matter to my relative but in return my relative accused my girl not the boy. In addition to this, I and her daughters have to work till morning to evening but it pays of a little, just some food for my family. It is a clear exploitation to my family but I have nothing to say as my relative already said that if I have any complain then I may go. For that reason now I never say anything to my relative and waiting for that day when I will find another job and will able to move my family from this house. At present I am praying to god for a new job by which I can be able to save my daughter from that dirty creature.

As stated before, social customs, relations and occasion plays a vital role in the life of village peoples' life (O'Neil). After talking to the affected people it is clear that all are feeling the absence of their past social life which is being vanished after the disaster. Many of them think that it is possible to recover all the losses but it is impossible to get that social life again which is also important for them. Religious institutions like mosques, temples are important places for the meet up of people. After RE both mosque and temple of that area are being washed away and that hampers the interaction among peoples. One of the respondent stated with sorrow that-

There is no field in this Eid. I am women, I was not able to go to the field for my Eid prayer but my husband and son used to go there which reminded me about the occasion of Eid (Note 31).

Again there are a few immolation of animal in this 'Kurbani eid' (Note 32). In this research area, before erosion there were more than twenty five families who were in the habit of giving 'Kurbani' (Note 33) but in this year only five families had given the 'Kurbani'. Actually this year most of the people of that area are not able sense how this occasion is being passed away. The situation is almost similar for the Hindu peoples. Recently there passed their most important occasion named 'Durga Puja' (Note 34), but it was not possible for them to enjoy it. Last year they have their own 'Pandal' (Note 35) where they celebrated the occasion. But now no one have the capability to donate money for pandal and also the place of the pandal as well as temple are drowned by the river. So this year the pandal of durga puja was not took places. Kyallani one of the respondents said about her feelings that:

As we did not have a pandal this year, I and my family had to visit the other villages pandal. To us it is not possible to enjoy the occasion in others territory. We visited the pandal of others and tried to celebrate the durga puja but unfortunately we did not have any spiritual connection with that pandal. Because it is impossible to substitute owns need by others goods (Note 36).

\subsection{Deprivation of Present and Their Future Hopes}

Actually, in the research area, there are only found the mourn of the victims of the river. They are so astonished and hopeless that they do not have the condition to think about their future. Most of them have no idea or plan for the future activities. According to Jahara:

We are here only to be the spectator of their future which will be written by god.

Nothing is in their hand now. For their living they are depending on other. Thus these women are given up to think about their future. They have no expectation. They just pull all things upon their fate.

Being displaced from their homestead, now these women have to cope up with various social and economic problems. They are now destitute and hopeless and have no expectation about their future. After RE, there evolved various problems in the area, which affects these women's social bondage as well their social capital. Thus before too late proper initiatives need to be taken otherwise the social bondage; which is so important in the rural life will seriously hindered.

\section{Actions Taken by Various Influential Actors after the Disaster}

This section deals with the actions and the opinions of Government, Non Government Organizations' (NGOs), Civil Societies, Local Leaders and person working with Media during and after the disaster. After the initiatives of leading groups, whether the situation of affected people is being changed or not, is described here. If the situations of these people are changed then how and what amount, is another discussable issue in this chapter. The chapter is divided into three sections. Section- A deals with Government activities whereas SectionB deals with NGO activities towards these affected people. The last section- $\mathrm{C}$ illustrates the activities of Media 
as well as the opinions of civil society members; local leaders toward the RE affected people. In this section it is described the pros and cons of various taken activities.

\subsection{Government Actions to Manage the Effects of the Disaster}

\subsubsection{A Sudden Catastrophe}

The incidence happened so fast and the pressure of water was so high that we did not able to do any immediate actions at that time. Between one and half hour the river erodes all (Note 37).

A big blow of water came and erodes all. Within a short notice the disaster is happened that no one had anything to do rather than seeing the destruction. Subsequent to erode government tried to manage the erosion by putting sand sack and slab on the eroding line of the river but that was not able to do any good. Being an officer of Bangladesh Water Development Board (BWDB), till now Mr. Nazrul has to stay in this area full time of his office hour. He believes that the most important thing that can improve the situation of this area is a well structured dam. Only after that it will be possible to control the river and flood. Many people came to him and asking help from him but as Officials of BWDB he has no deal with relief. When people heard about his inability that makes them unhappy as well him. He stated with sorrow that at present Government of Bangladesh (GoB) gives them nothing by which he can help these helpless people because:

There is no scope for BWDB to help people directly, we just able to engage ourselves in structural development (Note 38).

After the incidence, Local Member of Parliament (MP) came to this place and was stayed this area for two days to give relief to the affected people. He also visited all the affected area and gave order to the concerned authority to take the necessary steps. But his relief was not enough for this area as there are so many people who lost all because of river. Mr. Tabibor Rahman, member of Union Parishad (UP) (Note 39) describe the situation like this:

His [MP's] relief was like a drop of water in the desert. Honorable MP gave two thousands taka and eighteen kilogram of rice to hundred affected families which were very few in comparison with the peoples' losses. Moreover, there were more than three hundred families which were being affected by the disaster. As the amount of relief is low relief is given on the basis of severity of losses. For this reason many of the family in this area were not able to get government relief (Note 40).

Roads, schools, colleges, mosques, Union Parishad (UP) building everything are being washed away by the river. Government and honorable MP promised to rebuild all these institutions. People's life is seriously hampered because of the absence of these institutions. At present most of the people are unemployed. Some men now are migrate to the town to work as a day laborer but due to family and other reason it is not possible for women to go town and to work as a day laborer. For these unemployed women Local Government Engineering Department (LGED) introduced Rural Infrastructure Development Program by which these unemployed women can earn some money. According to Tabibor Rahman:

They have nowhere to go. Government gives them the work named 'Mati Kata' (Note 41) by which they are now employed. Because of their work the broken roads are now going to their previous situation (Note 42).

Women are working to reconstruct the affected roads. Hopefully within a few days all roads will go to their previous condition. The LGED is doing well here. It creates employment for these unemployed women in construction works. Because of these construction works the communication systems of this area are now improving. Both Mr. Tabibor Rahman and Mr. Nazrul Hossain tried to emphasize engaging local people in future development activities of government. Both of them express the similar opinion. According to their opinion:

A lot of work is going to happen in this area. Within a few days LGED and BWDB are going to rebuild a new dam here. If government engages local people in this works, it will better for them. This will create employment as well as an opportunity to change their situation (Note 43).

Like many of the respondent they also believe that the most important task is to dominate the pathway of river because without it, the incidence RE will continue to happen. Without taking this issue into concern a little relief will not able to make betterment of the people. Here Mr. Tabibor Rahman adds some words:

The issues like RE should take in concern more seriously as many lives, assets are attached with it. If government take proper initiatives after the small first crack in the dam [normally which is nothing to concern] this destruction might not happened (Note 44).

In $30^{\text {th }}$ September, 2012 there found a little crack in the dam. Both people and officers of BWDB observed that. Officers assured people that this is not an issue of fear as this dam is still good and can still prevent thrice time 
than the highest water level of this river. Unfortunately after ten or fifteen days a huge water flow came, which was the highest of its previous records and blow the dam as well as the locality.

The aid that comes from government is not sufficient and not able to do satisfactory change in the life of these people. Here the most important task for GoB is to reconstruct this area's dam and its communication system. Local affected people need to engage in these structural works. Because of their engagement in these work there will create employment opportunity for them as well as the area will also goes to its previous situation.

\subsection{NGOs Activities after the Disaster}

NGOs are considered playing the role of third sector in development process of this country. For that reason after the disaster in Sariakandi there goes some responsibilities upon them. There is mixed reaction among the people about the action of NGOs immediate after the calamity. Just after the erosion World Vision and Red Cross came to the area and established a temporary camp. World Vision gave tent in order to provide a short time accommodation to the homeless people whereas Red Cross was there to provide treatment. To most of the people the word NGO is synonymous to some renowned NGOs like BRAC, ASA and Grameen Bank etc. But unfortunately there were no initiative was taken by these NGOs immediate after the destruction and this made people both unhappy and annoyed. Maleka Begum expressed her feelings in this way:

Foreign companies [International NGOs] came and help us during our sorrow but our company did (Note 45) not even come to see us. In normal time they visit many times and say many lip service words but where are they? They are not here in the time of our need (Note 46).

In reality most of the NGOs are maintain the pyramid approach in decision making where most the decisions of NGOs are come from the central office. Without the approval and decision of the central office it is not possible for the branch office to take any initiatives. Mr. Hasinur Rahamn, branch manager of BRAC in Kutubpur Union told about his inability:

I am working here for 1.5 years. Many known people of mine lose all because of RE. Frequently I used to visit there and many people asked help from me and from my NGO. I really want to help them but I can only do what my office tells me to do. My hand is tied and my inability hurts me. Now I am going to reduce my visit in the affected area (Note 47).

He added that, but in some cases NGOs are helping people. I, myself and my office staffs are informally help many RE affected people by giving them advice and treatment. At present all loan repayment is closed for the sudden disaster and will be begin after 3-4 months. Now the repayment is stopped in order give these people some relief form repayment tension and also not to create another burden to these vulnerable people. Furthermore NGOs are taking plan to provide more loan to these helpless people. By this money, they can buy cattle and make themselves self dependant again. To him, this initiative of NGOs will bring a good result in people's life, particularly in women's life as the next loan program is mainly for the RE affected women.

There is no doubt that many good initiatives were taken by NGOs and many of them yet to come. But there are some people who are skeptic and disagree with the statements of NGOs. Mr. A. K. M. Reza, Headmaster of nearby high school is one of them. According to him:

They said they doing wellbeing, they help people. If they really want to help these people they should waive all the loans of affected people. S/he who loses all in erosion is not able to repay loan at present as well as after two or four months (Note 48).

There is no income as well as no employment for people of this area. Without creating any income generating activities it is impossible for the people to repay loan. For that reason, Mr. Reza thinks that withheld of repayment is not a good initiative at all. This pending of repayment is actually eyewash because this will not bring any good to the people. He added that most of the works of the NGOs are similar to this, they pretend their work as a very useful one but in reality that makes little good to the people. However, he also admitted that in many sector like child and maternal health, NGOs are doing good. He believes that if NGOs are taking issue of the suffering of the RE affected people seriously and take any specialized program in this area that will obviously bring good in the lives livelihoods of the effected people.

In our rural societies' development role of NGOs' are indivisible. Because of various NGO initiatives many people's life are being improved. In improving child and maternal health situation of this country, they are performing the key role. Thus it is also their liability to take initiatives in changing these helpless peoples' situation. For this reason they should provide some specialized project toward this affected community in order to help these people. 


\subsection{Role of Media \& Civil Society}

Media and civil society had the passive role here, but consequences of their role were very vital after the erosion. Media made a good coverage of RE and the distress of the people. The news was spread throughout the country and because of that government and other organizations able to know the sufferings. The relief was come to the area very quickly; Honorable MP and many officers of BWDB were come very sharply in the area after the disaster because the news spread very fast through electronic media and news paper. Mr. Rafiqul islam, journalist of ATN Bangla point up the role of media in this way:

Publicity makes popularity. Apart from raise the real scenario we do not have anything to do. But I can assure you that because of our publicity, both government and NGO actions were taken in this area very fast (Note 49).

It would be impossible for government or other organizations to realize the harshness of the disaster if there was no telecast or news. To him make the authority realized about the severity of RE was main success of media. Similarly as a member of civil society Mr. A. K. M. Reza also expressed the similar feelings. He along with many other renowned people of the locality provided food and shelter to these homeless people immediate after the RE but they were not able to do any permanent arrangement for RE affected people. At present as a member of civil society Mr. Reza can only give advice to these affected people.

Both Mr. Reza and Mr. Rafiqul agreed that only proper tributary management can reduce the distress of these people. Firstly, if a permanent well structured dam is established here that will obviously reduce the vulnerability of life and assets. And secondly, their risk free life will also able to accelerate the economic and social situation of their life. Mr. Reza opines that:

Social status will go to its previous position if their economic situation is improved. For their improvement they need income generating activities and shock free life which can only be ensured by a well thought-out dam (Note $50)$.

In this area people always have to cope up with shocks and hazards. That is why; they cannot improve their socio-economic condition. When they are assured that, they do not have to face the shocks; it will take stability as well as prosper to their life. He emphasizes to promote more works for women like 'Mati Kata' by LGED as a male can easily find a work but it is not easy for a woman to find a proper job. He added that only women's employment cannot take prosper in this area as women's lives is closely associated with families and their husbands. So it is also important to create employment for men also.

Furthermore they also emphasized to rebuild the affected schools, colleges and religious places. To them, an educated man has more option in employment and able to manage shocks more perfectly rather than an uneducated man. Mr. Rafiqul stated that:

The percentage of educated people in our Union is the highest in Bogra District. It is our pride. More educated people mean more option. But for that we need educational institutions which are now not available in our area (Note 51).

Education transforms a man into manpower. Both Mr. Rafiqul and Mr. Reza believe that if all people were educated, then the situation would not like this. Less people had to fight with unemployment. Mr. Rafiqul emphasizes to educate people and for this he is on the side of immediate construction of educational institutions. Besides, he also expressed his view about the quick reconstruction of various religious places. In rural area, religious places like mosque, temple etc are act as a place of getting together which have both sentimental and social values. Many commands and decisions related to the welfare of the locality are being declared from these institutions. Social bonding creates and established from here. So, early reconstruction of these religious institutions are also important to establish the social bonding again which was being in an inferior position due to RE.

\subsection{Puling Stone on Others Back}

All five respondent of five various groups, NGO people, government officials, local leaders, media and civil Society members have agreed in one issue that only a good tributary management will bring a positive effect in the life of peoples' life. They give many possible solutions like constructing dam, river dredging etc. Undoubtedly, all these construction responsibilities go upon the shoulder of government. But many of the respondents think that without taking so called humanitarian project, NGO should come forward to help government in structural development activities. As construction of dam or tributary management is not a small task, here government needs helping hands. GO-NGO collaboration will reduce the work load of both as well as there will also create a partnership between them. But on the issue GO-NGO collaboration there creates some confusion as both NGO and government officials expressed the opposite views. To both of them because of the 
other party the collaboration is not possible.

Local leader and Government officials think that NGO will never work together in a long term project with government. The main reason is that they are in lack of eagerness to work with government. Besides most of the projects' of NGOs are short term and based on foreign funded, that also restrain them to join with government. In Mr. Reza's words:

They will bow their heads in front of others not government (Note 52).

To work together NGO need to share their funds and other materials with government. They will never like to do that. Mr. Reza stated with sorrow that for funding they are ready to do everything in front of foreign donors but before our government NGOs are there to show their pride. Working in partnership with government will need to share their power and make them dependent upon government. Their autonomy will decrease and they will not able to do eyewash activities. Due to these reasons he thinks NGOs are not doing any influential part with government in tributary management.

In addition, Mr. Hasinur Rahman, branch manager of BRAC in Kutubpur Union gave the opposite speech. According to him:

Constructing dam is the responsibility of government. What we can do here now (Note 53)?

To him, NGOs are working as the helping hand in development which is extra assistance for government. Here government has less right to complain NGOs on this issue because tributary management is their responsibility not NGOs'. Like all, he also knows that in RE prone area construction of dam is more important than any other activities. He supports the association of work in constructing dam. But before that government needs to ensure the friendly work environment for NGOs and if it is ensured only then, NGOs will obviously come to work together. As both the government's and NGOs' have the same ideology that is helping people. According to Mr. Hasibur:

In long term process, NGOs will obviously come to help government but before that government has to create working atmosphere (Note 54).

In state monitored work there is too much political misuse of power, corruptions and red tapes which kills the eagerness of NGOs in GO-NGO collaboration works. Previously, in short term projects, NGOs were used to work with government but in many collaborative projects NGOs members had to humiliate by many political leaders. It is another reason because of what NGOs are not eager to work with government. But if government assured that these things will not happen again in future, NGOs will again work with government.

A big is destruction happened in the area because of RE. To improve the situation both government and NGO initiatives are needed. If these two actors stop blaming each other and helping people collaboratively, that will improve the situation of the area. This collaboration will also decrease their work burden. But for this, government has to provide secure work environment for NGOs' where NGOs have to show their eagerness.

This chapter deals with the opinion and their actions of various groups immediate after the RE. There everyone is in the positive side in managing river and the answer of how it will be managed is similar to everyone. Government took various initiatives here, of which most of them are structural development related. NGO's had taken many activities after the RE, but their main step was only to witheld the loan repayment for 2-3 month. Civil societies played some important role but their role is not so satisfactory. Many of the civil society members are established and are in big positions but they did not co-operate. With these RE affected people. If they came forward with a view to assist, the situation would have been better. Here comes the word collaboration of works between GO-NGO, and it turns into a debatable issue as both NGOs and government representatives are accusing one another. But if they stop blaming each other and work together for the area, that will bear a good result in this area. Here also found some commendation also which will be discussed in the recommendation part of next chapter.

\section{Vulnerability and Capabilities, How One Suppress Another: Findings and a Way Forward}

River is blessing to these affected women as well as also curses to them now. Once river fulfilled their life with crops and others resources but now it took all from them. Most of them were lived on agricultural works and their livelihoods are intimately allied with river. These women cannot even think their life without river. Thus, it needs pragmatic intervention from the proper authority to maintain the river flow in order to help these vulnerable women. This chapter deals with two sections. In section A, the key findings are summarized. It is summarized in the way in which they are vulnerable according to Moser's framework. Later the chapter analyze Nussbaum's list of ten capabilities is not fulfilled in relation to those affected women. Lastly, in section B, there 
given some recommendations about the procedure of improvement of social life of these vulnerable women.

\subsection{How Nussbaum's Capability Indicators and Its Deprivation in Women's Life}

\subsubsection{Life}

Nussbaum in her first indicator stated that 'everyone should be able to live a life of normal length' (Nussbaum 2005:171). However, after RE these women's life is not as same as it was in normal situation. They are now more exposed to the vulnerability. Basic needs of human life like - foods, shelter, security, are not ensured now. Equal security of all, it has been stated in the constitution of our country but there exists hardly any security to those homeless women. Rather than other distress, now security issues stands as first priority to them. They are always in fear of security, many incidence also happened and that fear of security directly affect their ability live a life of normal length.

\subsubsection{Bodily Health}

Bodily health is 'consisting of the ability to have good health to be adequately nourished and to have adequate shelter' (Alexander 2002: 8). Because of the anxiety of security, food, accommodation etc, these affected women have to face a negative effect on their health. After RE they suffered from various diseases but they were not able to get proper treatment. The only government hospital from which they used to take treatment was stopped its activities after being seriously destructed by erosion. They are now not in the situation to use money for private treatment. Thus they have no alternative rather than taking treatment from quark. This quark treatment has negative impact on their bodily health.

\subsubsection{Bodily Integrity}

Bodily integrity stands for 'being able move freely from place to place' and 'having opportunity for sexual reproduction and for choice in matters of reproduction' (Nussbaum 2005: 172). Now choice of reproduction is a luxury issues to them. One new born means one new mouth to feed. As their basic needs are not ensured now they have less choice of sexual reproduction. Moreover, their movement is also bounded with RE. Their movement is now dependent on surroundings. They cannot move from one place to another on their wish rather they have to move in search of their employment.

\subsubsection{Senses, Imagination and Thought}

Senses, imagination and thought refer to the 'ability to use the sense, to imagine and think and reason and to exercise these functions in a truly human way' (Alexander 2002:8). Here these vulnerable women are now not capable to do all these things. Education makes a human being capable enough to function in a human way. Most of the schools are affected and closed. Girls of this area are being deprived from formal education. Furthermore, for many families education is not so much important now, as to these families there are many important things that have to fulfill rather than education. Especially effected people are ignoring girls' education. Thus this indicator is not content here.

\subsubsection{Emotions}

'I do not have anything, how I can show sympathy to other? (Note 55)'

One the above way, Suruja Begum expressed her feelings. She feels from inside to help others when she see their distress but she is not able to. As now she is not capable enough to help them. Her words illustrate the real situation of the affected area. Emotions include the 'ability to love, to grieve, to experience longing, gratitude and justified anger' (Alexander 2002: 8). But here because of needy circumstance people have to bind their emotions.

\subsubsection{Practical Reason}

According to Nussbaum, practical reason implies 'forming a conception of the good and engaging in critical reflection about the planning of one's life' (Nussbaum 2005: 173). For the reason of unemployment these affected women are bound to engage themselves in various works which may not always preferable to them. There many of them are being both mentally and sexually abused and most of the case they have to tolerate all these odds. Because of the fear of losing their work these women are not able to protest the mistreatment. In many cases these women are lost their future hope. They just put their future on time and surroundings. At present, they do not have any future plan, which reflects the absence of practical reasoning in their life.

\subsubsection{Affiliation}

Affiliation refers to the 'ability to participate actively in many forms of social and political relationship, to speak in public, to be recognized as dignified beings whose worth is equal to that of others' (Nussbaum 2005: 173). 
Social affiliation is an important factor of rural life in that area. But now it is not as good in the life of these women as it was before. Due to sudden poverty after RE various social customs and occasions are not taken places. Moreover, various social and religious places like community center, temple, mosque where people used to meet each other are also drawn under water. Many known people with whom they had cordial relations, went to the town for work after RE. For this cause these women are now feeling the lack of affiliation. This lack of affiliation also has a negative impact on 'Social Capital', as affiliation between neighborhood lead to the social capital in rural area (Moser, 1998).

\subsubsection{Other Species}

'Other species is understood as the ability to live with concern for and in relation to animals, plants and the world of nature' (Alexander 2002: 8). Almost all the women owned livestock and many of them took animal husbandry as their profession. They used to bear cattle and sell before 'Kurbani Eid'. With the profit gained from selling cattle they were able maintain their family well. After RE many livestock were being float away and rest of them they sold in nominal price at that time. Three out of ten respondents expressed their feeling that they had feelings upon their pets but they were not able to provide food to them. That is why; they had to sell their pets which hurt them much.

\subsubsection{Play}

Play refers to the 'ability to enjoy leisure, laughter, and recreational activities' (Alexander 2002: 8). After RE these women have no work to do and most of their time they have to engage in search of works. Thus they do not have plenty of time which can be called as leisure. Actually at present, they are facing hard core poverty where there exists a little space for leisure, joy and recreational activities like- celebration of various occasions, drama, songs etc.

\subsubsection{Political and Material Control Over One's Environment}

The tenth capability of Nussbaum refers to women's ability to participate in politics, to seek employment and to enjoy a rewarding work life, and to control both land and movable assets (Alexander 2002: 8). With erosion of land and resources, political and material control is also decreased. As power is related to the ownership of assets, it is quite clear to these vulnerable women that they do not have the political and material control like before. Suruja Begum expressed her situation this way:

Before I feel something in me but after losing all that feeling is changed (Note 56).

Before RE, she had lands, resources as well as political and material control over her environment. But now she feels that she does not have that much control.

\subsection{Agency and Functioning in these Affected Women's Life}

Agency is best understood by Amartya Sen's explanation of an agent, defining an agent as someone who acts and brings about change, whose achievement can be evaluated in terms of his or her own values and objectives (Sen, 1999). But in their life this agent is absence by depending on which they can function their life suitably. Agency is the agent of change; it does not always need to be in a physical shape. Perhaps a motivation can perform the role of agent. Agency always focuses on the ability to personally choose the functionings one values, a choice that may not always correlate with personal well being. For example, when a person chooses to engage in fasting, they are exercising their ability to pursue a goal they value, though such a choice may not positively affect physical well-being. Amartya Sen explains this motivation as that person's own agency (Sen 1992).As an agent it is not needed to be guided by a pursuit of well being; agency achievement considers a person's success in terms of their pursuit of the totality of their considered goals and objectives. Similarly in this area, these affected women have their own agency, own factors of change. But in every time their agency is constrained by various factors as well as that also constrain their functioning as well as this also have negative impact on their overall well being and capability to enjoy full citizenship rights.

\section{Recommendations}

To give any recommendation about retaining the social status, first it is needed to measure how much Social Status is affected. Like economic losses it is not so easy to measure the social losses as it is a not possible measure social loss or social status in monetary values. But from the view point of many respondents it is clear that asset possession, land ownership are closely associated with social respect and social status. To retain previous social position the first step is to make these RE affected women economically empowered. Beside this many initiatives can be taken like:

Firstly, now most of the women are unemployed. Creating employment opportunity may be a big initiative to 
make them economically empowered, which is one of the preconditions of retaining social status. Here one thing needs to make sure that everybody needs to engage in works according to their qualification and social status. An educated woman may lose all in RE, she may be unemployed now, but she will not prefer to work as day laborer. Because of her engagement in this work she may able to earn money but her social status will decrease as working as a day laborer is not a prestigious job in this country. However, in case government can engage this educated woman in various management programs which is suitable to her social status. So engaging right person in right work is also an important issue in retaining social status for this area.

Secondly, resettling this affected community government takes a holistic approach. It is true that both men and women are being affected and vulnerable to this disaster. But the severity of helplessness is not same to these two groups. Because of gender division of labor and responsibility women are more opened to the vulnerability than men. In River Policy of Bangladesh (1997) it has given priority over resettling these affected community but there not stated any special attempt for women. So it is the responsibility of government to provide these women some legislative priority in employment.

Thirdly, because of RE, this area turns into a graveyard. roads, schools, fields, mosques, temples, community centre everything have been destroyed as along with homesteads. For improvement of the situation all these things need to reconstruct. Government is on the way to take various steps for the development of this area. Already many initiatives have been taken. Here, government has to ensure that the article 4.16c (Note 57) and 4.16d (Note 58) of National Water Policy (1997:22) is taking place here properly, where it is given priority to the river water affected community in engaging various works in their area. Thus, these disadvantaged women will get some opportunity to change their situation.

Fourthly, most of the farmers are now landless. They have no land to cultivate. It is now impossible for government to provide them cultivatable lands as land in this country is very little. Thus, by providing vocational training government can engage these farmers in various works. In future when sandbank will rise, government may distribute those lands among the affected farmers according to their severity of losses. Government can use its 'Khas' (Note 60) lands for accommodation of the affected farmers. Beside this, government can also introduce its 'Guchchhogram' (Note 61) (Cluster village) project here in order to take these disadvantage groups into mainstream. From Bangladesh's experience this cluster village project is quite effective to cope with the destruction of RE (Government have some positive results in Bhatpiary Guchchhogram, in Sirajgonj District where people are also affected by the river 'Jamuna') (Note 62).

Fifthly, a satisfactory amount of relief came in this affected from various sources; honorable MP gave rice, world vision gave treatment and so on. Most of them are for immediate actions. Because of the reliefs it might be possible to satisfy the immediate needs but in long run those reliefs had no positive impacts. Thus, instead of those immediate aids it may be better for these affected women to provide some loans or capital by which they can create employment opportunity.

Lastly and finally, the most important step that will help these people in present and in future is the tributary management, such as dredging, constructing dams, river bank management etc. Because a well constructed dam will obviously reduce people's uncertainty as well as vulnerability. Moreover, it will also bring sustainability in both their social and economic life.

\section{Conclusion}

Being the habitant of riparian area people of this country always have to face river erosion problem. Every year a large amount of habitant are being displaced due to RE. They lose all their material goods and shifted to another place to make the new settlement. With their migration they face both economic hardship and socio-economic deprivations, which is more severe for women. River erosion operates imperceptibly and thus it is able to attract little attention from man at its incipient stage (Jimoh.H.I. 2008:3). But the effects of RE is always devastating and this problem always will remain as a continuous threat to this country and its people. Better we have to find some practice to cope up with this problem which will include long-term policies and strategies as well as taking into count the social and institutional adjustment measures.

Moser in her frame work stated that a policy should be to identify what the poor have (assets) rather than they do not have to cope up with vulnerability (Moser 1998:23). Here people are experienced in many sectors like-agriculture, animal husbandry etc. So, policy for this area should take in concern about peoples' experience to engage this affected community in works. She states that assets ownership reduces the vulnerability. But here found the exception, in the case of RE the assets ownership of individual, not always able to reduce the vulnerability. For example two women may have the same assets but vulnerability of being affected by RE more severe to that woman who live near river. So, in river erosion case vulnerability can be also defined by surrounding rather than asset ownership. 
Furthermore, Moser argued that the capacity to manage assets also able to reduce vulnerability (Moser 1998: 23). It is true that pre-planned initiatives can reduce the risk of assets. But it is not always applicable for a disaster like river erosion. $\mathrm{RE}$ is such an unpredictable catastrophe where there is less opportunity for pre-planned management.

When people are displaced from their previous life style, the bad impacts of displacement affect their life style. Agency is what a person can do in line with his or her conception of the good (David A. 1995). Their option is now limited as well as conception of the good also constrained because of RE. They are now in absence of motivation where there is no functioning of their capabilities. If we look at the affected women's life we found that the ten indicators of Nussbaum's capabilities every of which is now absent in the life of the people of research area. At present they do not have the ability to plan for the future or to imagine for the future as they have only little access to their life planning. They pushed from their habitat which hampers their emotions and afflictions to others. Their recreational activities, control over political and material situation are also decreased as their access to resources are also decreased. As a whole now they do not have the ability to choose things about their lives, which means they have the inability in choice of freedom, which violates all the indicators of Nussbaum as well as the last stage of Sen.'s capability approach.

Already many fatalities have been occurred and many initiatives are also taken. But unfortunately in all initiatives there is a little space for social issues. Again in all cases either women are neglected or being sided away. But as the half part of population they needs proper attentions perhaps more attentions than men as their losses are also higher than men. So before it is too late it is needed to take proper schemes to improve these vulnerable women's situations.

\section{References}

Adaptation Processes of River-bank Erosion-induced Displacees in Bangladesh. Disasters ,28(1), 41-62. http://dx.doi.org/10.1111/j.0361-3666.2004.00242.x

Alexandar, J. M. (2002). Capability, Egalitarianism and Moral Selfhood' paper prepared for the Conference for the Conference Promoting Women's Capabilities: examining Nussbaum's Approach (pp. 1-25). University of Cambridge, UK. Retrieved from http://www.st-edmunds.cam.ac.uk/vhi/nussbaum/papers/alexande.pdf

Center for Environment and Geographic Information Services (CEGIS). (2009). Flood \& Erosion Prediction Division. Retrieved September 3, 2011, from http://www.cegisbd.com

Davies, S. (1993). Are coping strategies a cop out? Institute of Development Studies Bulletin, 24(4), 60-72. Fekete, A. (2008). The scale dependence of social and ecological vulnerability in context to river floods in Germany, EGU General Assembly 2008. Geophysical Research Abstracts (Vol. 10).

Ferguson, K. E. (1999). Patriarchy. In H. Tierney, Women's studies encyclopedia (Vol. 2, p. 1048). Greenwood Publishing.

Fertiliser Statistics. (2006-07). The Fertiliser Association of India, New Delhi.

Haque, C. (1988). Impact of Riverbank Erosion Hazards in the Brahmaputra-Jamuna.

Haque, R. (2011). The Floating Sex Worker in Dhaka City: A Human Rights Perspective. Lambert Academic Publishing.

Kothari, C. R. (1990). Research Methodology: Methods and Technique. New Delhi: New Age International Publishers.

Lipton, M., \& Maxwell, S. (1992). The new poverty agenda: An overview (Discussion Paper 306). Brighton: Institute of Development Studies.

Malti-Douglas, F. (2007). Encyclopedia of Sex and Gender.

May, T. (2001). Social Research: Issues, Methods and Processes.

Moser, C. O. N. (1998). The Asset Vulnerability Framework: Reassessing Urban Poverty Reduction Strategies, in World Development. Urban Poverty Reduction Strategies in World Development, 26(1), 1-19.

MoWCA (Ministry of Women and Children Affairs). (2011). National Child Policy, Government of the People's Republic of Bangladesh.

Nancy D. G. (2004), Erosion and Scour. Stream hydrology: an introduction for ecologists.

Naoki, M., Kengo, S., \& Pech, S. (2008). Bank erosion the Mekong River Basin: Is bank erosion in my town caused by the activities of my neighbors? 
Nussbaum, M. C. (1999). Sex and Social Justice. Oxford University Press.

Nussbaum, M. C. (2001). Women and Human Development: The Capabilities Approach. USA: Cambridge University Press.

O’ Brian (2010). princeton.edu/papers/100534. Philadelphia: Open University Press.

Ratha, K., Touch, S., Sokhom, H., \& Akara, O. (2010). The Impacts of Climate Change on Bank Erosion and Its Effects on Socio-Economic and Environment.

Robeyns, I. (2003). The Capability Approach: An Inter disciplinary Introduction. Amsterdam: Amsterdam School of Social Sciences Research (pp. 1-19). Science Ltd. Great Britain.

Sen, A. (1983). Development: Which Way Now? Economic Journal, 93(372), 745-762. http://dx.doi.org/10.2307/2232744

Sen, A. (1999). Development as Freedom. New York: Knopf.

Streeten, P. S., Burki, M., Haq, N., H., \& Stewart, F. (1981). First Things First: Meeting Basic Needs in Developing Countries. Oxford: Oxford University Press.

Suad, J. (2005). Family, Body, Sexuality and Health. Encyclopedia of Women \& Islamic Cultures (Vol. 3).

Uddin, A. F. M. A., \& Basak, J. K (2012), Effects of Riverbank Erosion on Livelihood. Retrieved from http://www.indiaenvironmentportal.org.in/category/author

Wahab, S, A., \& Haque, R. (2011). Solar Energy as Source of Electricity: Is It a Blessing or a Burden for People Living In Shirajganj, Bangladesh? It was the age of darkness. Lambert Academic Publishing.

Wasta, R., \& Haque, R. (2011), Feminization of Environment. Is the National Water Policy-1998, Gender Sensitive? Lambert Academic Publishing.

\section{Notes}

Note 1. Ministry of Water Resources.

Note 2. Center for Environment and Geographic Information Services (CEGIS), 2009, Flood \&Erosion Prediction Division. Retrieved September 3, 2011, from http://www.cegisbd.com

Note 3. Discussed latter.

Note 4. Poverty is the deprivation of food, shelter, money and clothing that occurs when people cannot satisfy their basic needs. Poverty can be understood simply as a lack of money, or more broadly in terms of barriers to everyday life. And people who are the victim of poverty are poor people (Haughton, J., Khandker, S., Handbook on Poverty and Inequality.

Note 5. O’Neil. Brian, Women and Displacement: A Case Study of Women displaced by Ganga erosion in Malda district of West Bengal in India

Note 6. Patriarchy literally means the rule of the father (Kathy E. 1999). From the word Patriarchy it comes the word patriarchal society, which stands for a social system in which the male is the primary authority figure central to social organization and the central roles of political leadership, moral authority, and control of property, and where fathers hold authority over women and children. (Fedwa 2007)

Note 7. Development is a normative concept referring to multidimensional process. At the common sense it means positive change of our outside and mind set.

Note 8. Here development stands for Economic development which is generally refers to the sustained, concerted actions of policymakers and communities that promote the standard of living and economic health of a specific area. Economic development can also be referred to as the quantitative and qualitative changes in the economy (Sen, 1983:745-762).

Note 9. A means of living, especially of earning enough money to feed oneself etc.

Note 10. Naoki, M. Kengo, S \& Pech, S. (2008). Bank erosion the Mekong River Basin: Is bank erosion in my town caused by the activities of my neighbors?

Note 11. Biryani is a set of rice-based foods made with spices, rice and meat, fish, eggs or vegetables.

Note 12. Author's Interview with Monira, 28thOctober 2012, Chondonbaisha in Sariakandi, Bogra.

Note 13. A means of living, especially of earning enough money to feed oneself etc. 
Note 14. Author's Interview with Surja Begum, 28th October 2012, Chondonbaisha in Sariakandi, Bogra.

Note 15. The bigha is a unit of measurement of area of a land, commonly used in Nepal, Bangladesh and in a few states of India. One bigha is ranged from 1,500 to 6,771 square meters. (Fertiliser Statistics, 2006-07, The Fertiliser Association of India, New Delhi)

Note 16.Author's Interview with Respondent 11, 28thOctober 2012, Chondonbaisha in Sariakandi, Bogra.

Note 17. Author's Interview with Jahara, 28thOctober 2012, Chondonbaisha in Sariakandi, Bogra.

Note 18. http://www.panosradiosouthasia.org/prsa/prsaarchives.php?id=86, last viewed 12th December, 2012

Note 19. Ibid.

Note 20. Author's Interview with Moyna, 28thOctober 2012, Chondonbaisha in Sariakandi, Bogra

Note 21. Author's Interview with Rupali, 28thOctober 2012, Chondonbaisha in Sariakandi, Bogra

Note 22. Here pure stands for virginity.

Note 23. Joseph. Suad, Encyclopedia of Women \& Islamic Cultures, Volume 3: Family, Body, Sexuality and Health.

Note 24. ibid

Note 25. Author's Interview with Kyallni, 28thOctober 2012, Chondonbaisha in Sariakandi, Bogra

Note 26. ibid

Note 27. Author's Interview with Thakurdesh, 28thOctober 2012, Chondonbaisha in Sariakandi, Bogra

Note 28. Here the word "Kharap kaj" stands for sexual relation.

Note 29. Author's Interview with Surja Begom, 28thOctober 2012, Chondonbaisha in Sariakandi, Bogra

Note 30. A major Muslim religious occasion where happened the immolation of animals in name of god and the meat of that animals is being distributed among the poor and relatives.

Note 31. Slaughtering of animal in name of god.

Note 32. Is an annual Hindu festival in South Asia that celebrates worship of the Hindu goddess Durga.

Note 33. Is fabricated structure, either temporary or permanent, in religious ceremonies.

Note 34.Author's Interview with A. K.M. Nazrul Hossain, SAE, Bangladesh Water Development Board (BWDB), 28thOctober 2012, Chondonbaisha in Sariakandi, Bogra.

Note 35. ibid

Note 36. Union Councils (Union Parishads or just Union) are the smallest rural administrative and local government units in Bangladesh

Note 37. Author's Interview with Tabibor Rahman, 28thOctober 2012, Chondonbaisha in Sariakandi, Bogra.

Note 38. A development program runs by LGED. The basic objective was to provide short term employment for the destitute women that are essential for their survival as well as for their economic upliftment.

Note 39. ibid

Note 40. Author's Interview with A. K. M. Nazrul Hossain, 28thOctober 2012, Chondonbaisha in Sariakandi, Bogra.

Note 41. Author's Interview with Tabibor Rahman, 28thOctober 2012, Chondonbaisha in Sariakandi, Bogra.

Note 42. Here our company stands for local NGOs.

Note 43. Author's Interview with Maleka Begum, 28thOctober 2012, Chondonbaisha in Sariakandi, Bogra.

Note 44. Author's Interview with Hasinur Rahamn, 28thOctober 2012, Chondonbaisha in Sariakandi, Bogra.

Note 45. Author's Interview with A. B. A. Reza, 28thOctober 2012, Chondonbaisha in Sariakandi, Bogra.

Note 46. Author's Interview with Mr. Rafiqul islam, 28thOctober 2012, Chondonbaisha in Sariakandi, Bogra.

Note 47. ibid

Note 48. ibid

Note 49. ibid 
Note 50. ibid

Note 51. ibid

Note 52. Author's Interview with Suruja Begum, 28thOctober 2012, Chondonbaisha in Sariakandi, Bogra

Generally 25 percent of the earthwork of any public water project will be offered to specific target groups or beneficiaries.

Note 53. All opportunities are explored and efforts undertaken to ensure that the landless and other disadvantaged groups are directly involved in participatory management of local water resources.

Note 54 . Land that is possessed by government.

Note 55. See appendix

Note 56. http://www.newstoday.com.bd, last viewed 12th December, 2012

\section{Copyrights}

Copyright for this article is retained by the author(s), with first publication rights granted to the journal.

This is an open-access article distributed under the terms and conditions of the Creative Commons Attribution license (http://creativecommons.org/licenses/by/3.0/). 